\title{
Climate Change-Greenhouse Gas Emissions Analysis and Forecast in Romania
}

\author{
Georgiana Moiceanu ${ }^{1}$ (D) and Mirela Nicoleta Dinca ${ }^{2, *(1)}$ \\ 1 Department of Management and Entrepreneurship, University POLITEHNICA of Bucharest, \\ 060042 București, Romania; georgiana.moiceanu@upb.ro \\ 2 Department of Biotechnical Systems, University POLITEHNICA of Bucharest, 060042 București, Romania \\ * Correspondence: mirela.dinca@upb.ro; Tel.: +40-76-193-8017
}

check for updates

Citation: Moiceanu, G.; Dinca, M.N. Climate Change-Greenhouse Gas Emissions Analysis and Forecast in Romania. Sustainability 2021, 13, 12186. https://doi.org/10.3390/ su132112186

Academic Editors: Jinsoo Kim and Tomonobu Senjyu

Received: 30 September 2021 Accepted: 2 November 2021 Published: 4 November 2021

Publisher's Note: MDPI stays neutral with regard to jurisdictional claims in published maps and institutional affiliations.

Copyright: (c) 2021 by the authors. Licensee MDPI, Basel, Switzerland. This article is an open access article distributed under the terms and conditions of the Creative Commons Attribution (CC BY) license (https:/ / creativecommons.org/licenses/by/ $4.0 /)$.

\begin{abstract}
Greenhouse gases (GHG), such as carbon dioxide, methane, nitrous oxide, and other gases, are considered to be the main cause of global climate change, and this problem has received significant global attention. Carbon dioxide has been considered the most significant gas contributing to global climate change. Our paper presents an analysis of the greenhouse gas emissions in Romania along with a forecast for the years to come. For the study, data from the National Institute of Statistics and Eurostat were gathered and used for the analysis in order to present the results. To obtain the results, the data gathered were analyzed using forecasting methods that can be of help in solving some uncertainties that surround the future. The greenhouse gas (GHG) emissions trends in Romania were analyzed both for linear and exponential function methods. The obtained results showed that the linear function analysis of total GHG emissions in Romania had a forecast accuracy higher than the exponential function method. From the analytical methods used we can draw the conclusion that the emissions are on a descending scale and choosing a proper method is important in analyzing data.
\end{abstract}

Keywords: climate change; greenhouse gas emissions; environment; carbon dioxide; EU GHG emissions; forecast analysis; chronological series analysis; analytical method analysis

\section{Introduction}

The biggest threat to the environment and also to a country's economic situation comes from the climate changes that occur. An analysis over the past 150 years revealed an increase in median temperature by one degree Celsius [1]. The highest temperatures ever recorded since 1850 until now happened after 1995. It is estimated that the annual median temperature by 2100 will increase by 4 to 5 degrees Celsius [2,3]. The Fourth Assessment Report by Working Group I of the Intergovernmental Panel on Climate Change (IPCC) estimated that global climate change is forecasted to result from six scenarios of GHG aerosol emissions, taken from a larger set of scenarios from the IPCC Special Report on Emissions Scenarios. Working Group I assessed climate change under these scenarios, including ocean-atmosphere general circulation models (GCMs) and simple climate models (SCMs), with some models that include carbon-cycle feedback for the climate-change projections. These scenarios are identified as A1FI, A1B, A1T, A2, B1, and $\mathrm{B} 2$, with the lowest cumulative emissions being projected by the $\mathrm{B} 1$ scenario and the highest by A1FI. They estimated that the A1FI emissions scenario would lead to a warming of $4{ }^{\circ} \mathrm{C}$ in the 2070s relative to pre-Industrial temperatures [4].

According to Liu and Raftery [5], based on a fully statistical probabilistic model for forecasting future fossil fuel and industry carbon emissions, the probability of staying below a warming of $2{ }^{\circ} \mathrm{C}$ is only $5 \%$.

The impact of climate change can be seen mostly through extreme climate events like tornados, heatwave, floods, etc., all happening more and more often both in Europe as well as in other parts of the world [6]. Natural ecosystems, water reserves, and human 
health are highly affected in each part of the globe. For example, in Europe, rains have increased in the north/northwest side. The economic sector, once developed in accordance with the region and the climate, now will be affected and produce suffering for the natural ecosystem, with devastating consequences, some implying the loss of biodiversity.

Sustainable climate change systems in the context of decreasing environmental impact is a key subject included in the broader topic of environmental protection in Europe. The Sustainable Development Report 2019 mentions the need to take urgent action to combat climate change and its impact [7]. In this respect, the European Commission created the legal framework and policies for climate and energy from 2020 to 2030-COM (2014), which set one important target, reducing greenhouse emissions by 2050 to under $80-85 \%$, which is actually a level below the level recorded in 1990 [8]. In addition, the new targets for Europe set by the EU mentions the point of reaching a climate-neutral continent by 2050, a goal set in the European Green Deal. The related legislation is binding and involves a commitment to climate neutrality [9].

The climatic sensitivity of global wildfire activity was analyzed by researchers [10]. Using satellite-derived wildlife products and processes, they were able to present the climate factors that influence wildfires. Process-oriented fire models helped to simulate past and future wildfires. Thus, their results present the spatiotemporal dynamics of burned areas along with their possible response to climatic factors [10].

Different areas around the world were analyzed in order to highlight the features of regional climate change. King et al. [11] chose to analyze the glaciers draining from the Geladandong ice caps since the 1960s. Fu et al. [12] presented the results related to climate change in the Tibetan Plateau using global climate change model simulation.

Surface air temperature and precipitation are the climatic factors that are usually analyzed [13]. Global temperature trend analysis was the main topic in several scientific articles [14-16]. Mudelsee M. [16] used a system to generate a time series of global surface temperature.

The earth system is influenced highly by living organisms because they impact the formation of clouds and atmospheric dust and alter the concentration of GHG in the atmosphere [17-19]. The World Meteorological Organization specified that the period between the years 2011 and 2020 was the warmest decade on record [20]. According to scientists and environmental experts, to be able to stop this level of change, to stop biodiversity change, it is necessary to reduce GHG emissions along with applying at a worldwide level a proper legal framework and directive that contains strategies and actions for the future. The difference between being able to fulfil the legal framework set in place and moving ahead as the situation is now will be determined by the financial capacity of each country.

Regarding the studies conducted that analyzed GHG emissions, many concluded that the main responsible factor for climate change disaster is GHGs of anthropogenic origin [21-24].

According to the Kyoto Protocol, GHGs include six gases, namely, carbon dioxide $\left(\mathrm{CO}_{2}\right)$, methane $\left(\mathrm{CH}_{4}\right)$, nitrous oxide $\left(\mathrm{N}_{2} \mathrm{O}\right)$, hydrofluorocarbons (HFCs), perfluorocarbons (PFCs), and sulfur hexafluoride (SF6) [25]. The most common GHG emitted by human activities is carbon dioxide. Anthropogenic GHGs include carbon dioxide from burning fossil fuels, deforestation, land clearing for agriculture, degradation of soils, methane from agricultural activities, waste management, energy use and biomass burning, nitrous oxide from agricultural fertilizers, and fluorinated gases from industrial processes and refrigeration $[26,27]$.

In State of the Global Climate 2020 report it is mentioned that globally averaged mole fractions of carbon dioxide $\left(\mathrm{CO}_{2}\right)$ have already exceeded 410 parts per million (ppm), and if the $\mathrm{CO}_{2}$ concentration follows the same pattern as in previous years, it could reach or exceed 414 ppm in 2021 [20]. 
Alhindawi et al. [28] investigated the GHG emissions from the transportation sector and developed a multivariate linear regression and double exponential smoothing model for the projection of GHG emissions from this sector.

Andrejiova et al. [29] presented in their research the current situation regarding GHG emissions in the air in 27 European Union (EU-27) member states. The authors compared the European Union member states on the basis of 15 examined parameters (population, area, the number of commercial airports with more than 15,000 passengers per year, the total GHG emissions, the amount of aviation GHGs, the amounts of individual aviation GHG emissions $\left(\mathrm{CO}_{2}, \mathrm{~N}_{2} \mathrm{O}, \mathrm{CH}_{4}, \mathrm{HFC}\right)$, the total amount of PM2.5 particulate matter in the air, etc.) by applying the principal component analysis method and a cluster analysis. They reported that in the years 2012 to 2018 in almost all EU-27 member states, there was an increase in aviation GHG emissions.

In another study, Saleh et al. [30] investigated $\mathrm{CO}_{2}$ emissions using a prediction support vector machine (SVM) model, which considered variable energy consumption that has an impact on the emergence of $\mathrm{CO}_{2}$ emissions. The authors considered electrical energy and burning coal as energy consumption that directly affects increasing $\mathrm{CO}_{2}$ emissions. The trial-and-error approach was applied in order to obtain a better prediction model with lower error.

Li et al. [31] proposed a new forecasting model for carbon emissions related to energy consumption in the Beijing-Tianjin-Hebei region from 2017 to 2030 based on the extreme learning machine (ELM) algorithm optimized by grey prediction theory and a support vector machine (SVM). They proved that the SVM-ELM model has higher prediction accuracy than the SVM model and ELM model through the analysis of empirical research. In the same way, Zhou et al. [32] proposed a combined forecasting model based on the rough set and grey prediction models as well as the support vector machine (SVM) model to forecast carbon emissions from 2012 to 2017. They used the data on Chinese carbon emissions from 1992 to 2011.

Another study that used the support vector machine method for the prediction of $\mathrm{CO}_{2}$ was conducted by Sun et al. [33]. The authors presented a method based on principal component analysis (PCA) and an improved least squares support vector machine (LSSVM) prediction.

Lee et al. [34] analyzed the uncertainty of GHG emissions using the parametric Monte Carlo simulation method and the non-parametric bootstrap method, whereas Akyol and Ucar estimated the greenhouse gas emissions of Turkey in the year 2030 using a time series forecasting algorithm in the WEKA (Waikato Environment for Knowledge Analysis) data mining software [35].

Kijewska and Bluszcz [36] analyzed the level of differentiation of European Union member states in terms of the emissions of four greenhouse gases and identified groups of similar countries based on these criteria. The authors used a taxonomic method-cluster analysis, namely, the agglomerative algorithm, which enables the extraction of objects that are similar to each other from the data and then merges them into groups. Their conclusion was that among the largest emitters of greenhouse gases are Germany, the United Kingdom, France, Turkey, Poland, Italy, and Spain.

In their research, Ding et al. [37] explored the dynamic relationship between business growth and carbon emissions performance by constructing and using a time series model to predict the trend of carbon emissions. They used the time series method (ADF unit root test, cointegration test, and VAR model) to investigate 805 companies listed on the Taiwan Stock Exchange from 2012 to 2017. Their results showed a long-term dynamic relationship between business growth and carbon emissions performance. Tubiello et al. [38] assessed the GHG emissions from drained organic sols. To better highlight the emissions, they were able to organize the data in two important domains—land use and agriculture-and then just the $\mathrm{N}_{2} \mathrm{O}$ and $\mathrm{CO}_{2}$ emissions per unit area were used for the analysis. Their conclusion showed a significant presence of $\mathrm{CO}_{2}$ in the emissions from drained organic soils. 
GHG emissions were also analyzed from a positive point of view by seeing whether there is a connection between agricultural GHG emissions and productivity growth [39]. The analysis continued and analyzed GHG emissions in correlation to renewable energy [40] and non-renewable energy. It was observed that the $\mathrm{CO}_{2}$ emissions decreased in the case of renewable energy.

To summarize, the EU efforts and thus, Romanian efforts, focus on reducing GHG emissions, keeping in mind along the way that this process should not interfere with a country's economic state.

The present manuscript's objective was to conduct an analysis on GHG emissions in Romania in the EU context starting with the legislative framework in both the EU and Romania, as well as aspects of GHG emissions in the EU and Romania, and then conduct a forecast analysis of GHGs using data from Eurostat and the Romanian National Statistic Institute.

According to the 4th Biennial Report of Romania, the general trend of GHG emissions in Romania shows a strong decrease compared to the base year. Thus, between 1989 and 2018, total GHG emissions (excluding Land Use, Land-Use Change, and ForestryLULUCF) decreased by $62.10 \%$ and net GHG emissions (including LULUCF) decreased by $68.32 \%$. $\mathrm{CO}_{2}$ had the largest share of total GHG emissions, followed by $\mathrm{CH}_{4}$ and $\mathrm{N}_{2} \mathrm{O}$. The emissions trends by sector in 2018 was as follows: Total GHG emissions from the energy sector accounted for the largest share $(66.32 \%)$, followed by those from the agriculture sector, with a share of $17.1 \%$, and those from industrial processes and the product-use sector, with a share of $11.58 \%$ [41].

\section{Materials and Methods}

In order to reach the research objective, we used data from the official statistics platforms Eurostat and INS (Romanian National Statistic Institute, Bucharest, Romania), focusing on the total GHGs emissions in Romania and the EU, GHG emissions by sector (energy, industrial process and product usage, waste and agriculture), GHG emissions per capita, and GHG emissions intensity of energy consumption. Our intention was to deepen the correlation between the two databases. The forecast analysis was done using MSOffice Excel statistics using the forecasting tools available. Forecasting theory was chosen based on the fact that the databases had past information that was of help for future prediction. Before applying the forecasting tool, the data were pre-processed because we observed missing data from some states in the EU.

Since we had a set timeline, year by year, a forecast analysis using chronological series was used. The chronological time series ( $\mathrm{SCr}$ ) is a set of values that a certain value can take (quantitative and qualitative) at different moment or during successive timeframes. In our case, the timeframes were successive and had the same length, so we used SCr of moments with equal timeframes between moments. Knowing this, the median indicators of the chronological time series were calculated.

- Median level for SCr intervals

This can be calculated as a simple arithmetic average by the ratio between the sum of the series terms and the number of terms:

$$
\bar{y}=\frac{\sum_{t=1}^{n} y_{t}}{n}
$$

where we have the following terms:

n-number of terms;

$y_{t}$-the series terms;

- $\quad$ SCr moments with equal intervals between moments-the median level is calculated as a chronological simple average, a particular case of the chronological weighted average where $h_{1}=h_{2}=\ldots=h_{\mathrm{n}}-1=h_{\mathrm{n}}=h$ and $h$ represents the interval length (in time units). 
Then we have:

$$
\overline{y_{c r}}=\frac{\sum_{i=1}^{n-1} A_{i}}{\sum_{i=1}^{n-1} h_{i}}=\frac{\frac{\left(y_{1}+y_{2}\right) h}{2}+\frac{\left(y_{2}+y_{3}\right) h}{2}+\cdots \frac{\left(y_{n-1}+y_{n}\right) h}{2}}{(n-1) h}=\frac{y_{1} \frac{h}{2}+y_{2} h+\cdots+y_{n-1} h+y_{n} \frac{h}{2}}{(n-1) h}=\frac{\frac{y_{1}}{2}+y_{2}+\cdots+y_{n-1}+\frac{y_{n}}{2}}{n-1}
$$

where:

- $\quad$ hi represents the length of the intervals between moments $t_{i}$ and $t_{i+1}, i=1, \ldots, n-1$, expressed in time units.

- $\quad$ Ai represents the simple moving chronological average (for example: $A_{1}=\left(\left(y_{1}+y_{2}\right)\right.$ $\times h) / 2$ ).

- Absolute average change (absolute average gain)

This indicator can be determined as a simple average based on absolute modifications (changes) with a mobile base using the equation:

$$
\bar{\Delta}=\frac{\Delta_{n / 1}}{n-1}=\frac{y_{n}-y_{1}}{n-1}
$$

$y_{n}$-the last term of the SCr;

$y_{1}$-the first term of the $\mathrm{SCr}$;

$n$-number of terms.

This indicator/parameter shows with how many concrete unit measures the level of process is modified, on average, during the timeframe analyzed.

- Dynamic average parameter (increase or decrease)

This parameter can be determined as a geometrical average of the mobile base coefficients (parameters) using the following equation:

$$
\bar{I}=\sqrt[n-1]{\frac{y_{n}}{y_{1}}}
$$

This parameter shows how many times, on average, the level of the analyzed process has been modified considering the timeframe considered for calculating.

- Dynamic rhythm (relative average change or relative median gain or median increase/ decrease ratio)

$$
\bar{R}=\bar{I}-100=(\bar{I}-1) 100[\%]
$$

This shows the percentage of increase/decrease, on average, of the process level from one period to another over the entire time horizon.

The analytical method-linear trend analysis and exponential trend analysis were used because they offer a more exact adjustment of the chronological series because they consider all the $\mathrm{SCr}$ terms.

The equation that describes the linear trend analysis is:

$$
\hat{y_{t}}=a+b
$$

Based on this, the parameters $a$ and $b$ of the function were calculated as follows:

$$
\begin{aligned}
& a=\frac{\sum y_{t}}{n}=\bar{y} \\
& b=\frac{\sum t \times y_{t}}{\sum t^{2}}
\end{aligned}
$$


Regarding the exponential trend, the equation that best describes the analysis is:

$$
\hat{y}_{t}=a \times b^{t}
$$

For the exponential trend after the logarithm of the relationship and applying the least squares method, we can determine parameters $a$ and $b$ as follows:

$$
\begin{gathered}
\log a=\frac{\sum \log y_{t}}{n} \\
\log b=\frac{\sum t \times \log y_{t}}{\sum t^{2}}
\end{gathered}
$$

\section{Results and Discussion}

\subsection{Brief Overview of GHG Emissions in the European Union}

In order to achieve a sustainable future for the next generations, the EU is constantly developing methods and tools to monitor the progress of European countries in reducing the impact of GHG emissions. A reduction in the negative impact of GHG emissions can be achieved through an increase in public and industry awareness. The strategic EU documents that are considered to have an impact on GHG emissions are included in

\begin{tabular}{|c|c|c|}
\hline Strategic Document & Main Actions & Source \\
\hline European Green Deal & $\begin{array}{c}\text { "The European Commission proposed in September } \\
2020 \text { to raise the } 2030 \text { GHG emission reduction } \\
\text { target, including emissions and removals, to at } \\
\text { least 55\% compared to 1990." }\end{array}$ & $\begin{array}{c}\text { https:/ / ec.europa.eu/info/strategy/priorities-20 } \\
\text { 19-2024/european-green-deal_en, accessed on } \\
21 \text { August } 2021\end{array}$ \\
\hline $\begin{array}{l}\text { Regulation on the Governance of the } \\
\text { Energy Union and Climate Action }\end{array}$ & $\begin{array}{c}\text { "EU has adopted integrated rules to ensure } \\
\text { planning, monitoring and reporting of progress } \\
\text { towards its } 2030 \text { climate and energy targets and its } \\
\text { international commitments under the Paris } \\
\text { Agreement." }\end{array}$ & \\
\hline $\begin{array}{c}\text { EU Emissions Trading System } \\
\text { Effort Sharing Regulation with Member } \\
\text { States }\end{array}$ & $\begin{array}{c}\text { "All sectors will contribute to the achievement of } \\
\text { the } 40 \% \text { target by both reducing emissions and } \\
\text { increasing removals." }\end{array}$ & $\begin{array}{c}\text { https:/ / ec.europa.eu/clima/policies/ets_en } \\
\text { https:/ / ec.europa.eu/clima/policies/effort_en, } \\
\text { accessed on } 21 \text { August } 2021\end{array}$ \\
\hline European Climate Law & $\begin{array}{l}\text { "The European Commission proposed on } 4 \text { March } \\
2020 \text { the first European Climate Law to enshrine } \\
\text { the } 2050 \text { climate-neutrality target into law." }\end{array}$ & $\begin{array}{l}\text { https:/ / ec.europa.eu/clima/policies/eu-climate- } \\
\text { action/law_en, accessed on } 21 \text { August } 2021\end{array}$ \\
\hline $\begin{array}{c}\text { Long-term low GHG emission } \\
\text { development strategy of the EU and its } \\
\text { member states }\end{array}$ & $\begin{array}{l}\text { "The endorsement of the climate neutrality } \\
\text { objective was reached following an inclusive } \\
\text { institutional and societal debate based on the } \\
\text { strategic long-term vision proposed by the } \\
\text { European Commission which includes a detailed } \\
\text { analysis of solutions that could be pursued for the } \\
\text { transition to a net zero GHG emissions economy } \\
\text { and insights regarding the corresponding strategic } \\
\text { priorities and an enabling framework that would } \\
\text { allow reaching climate neutrality by 2050." }\end{array}$ & $\begin{array}{l}\text { https:// unfccc.int/documents/210328, accessed } \\
\text { on } 14 \text { October } 2021\end{array}$ \\
\hline $\begin{array}{l}\text { A Clean Planet for All-A European } \\
\text { strategic long-term vision for a prosperous, } \\
\text { modern, competitive, and climate-neutral } \\
\text { economy }\end{array}$ & $\begin{array}{l}\text { "Research, development and demonstration will } \\
\text { significantly reduce costs of breakthrough } \\
\text { technologies. This will lead to genuinely new } \\
\text { products replacing today's industrial products, } \\
\text { such as carbon fibre or stronger cements reducing } \\
\text { the volume of production while increasing product } \\
\text { value. A net-zero GHG emissions economy will see } \\
\text { new business concepts develop with re-use and } \\
\text { additional services at its core." }\end{array}$ & $\begin{array}{l}\text { https:/ / eur-lex.europa.eu/legal-content/EN/ } \\
\text { TXT/?uri=, accessed on } 21 \text { August } 2021\end{array}$ \\
\hline
\end{tabular}
Table 1.

Table 1. Strategic EU documents impacting GHG emissions and the main actions mentioned.

According to Eurostat and the scientific community, the GHG emissions resulting from human activity are the main cause of environmental decline, mainly Earth's average 
temperature increase over the last 250 years. The GHG emissions generated in 2019 in the EU were $8.4 \%$, which was less than the GHG emissions in 2000, according to Eurostat. There was a period when the emissions slightly increased from 2002 to 2008, when the trend started to descend. The GHG emissions recorded by Eurostat presented the highest value for Luxemburg, with 30.8 metric tons per capita, in 2005, which in 2019 decreased to 20.3, whereas the smallest value recorded was in Latvia.

Romania is part of the new GHG emissions system that needs to be properly implemented in all of Europe. Efforts and significant investments have been made to align the local policies and practices to the European Community regulations. The situation is evolving and changes are made constantly.

In Figure 1, the total national emissions of the so-called "Kyoto basket" of GHGs are presented for the EU states. This includes carbon dioxide $\left(\mathrm{CO}_{2}\right)$, methane $\left(\mathrm{CH}_{4}\right)$, nitrous oxide $\left(\mathrm{N}_{2} \mathrm{O}\right)$, and the so-called F-gases (hydrofluorocarbons, perfluorocarbons, nitrogen trifluoride (NF3), and sulfur hexafluoride (SF6)). The EU member states report the emissions annually according to the United Nations Framework Convention on Climate Change (UNFCCC). As can be seen in Figure 1, there are still some differences among EU states. In Figure 1, the cumulative data are presented for each country, whereas for the European Union-27 countries, only the cumulative average is presented.

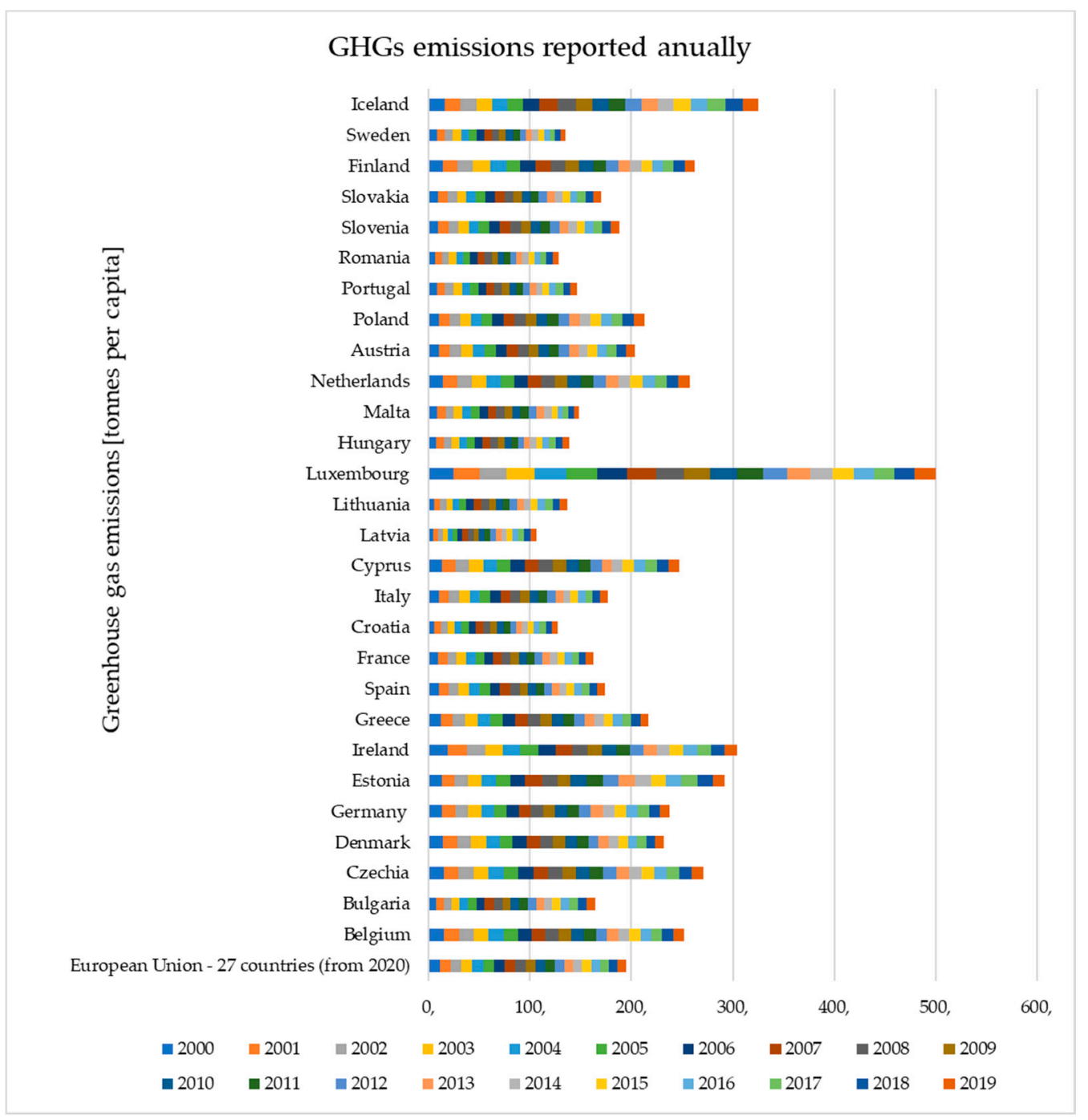

Figure 1. GHG emissions per capita (source: own elaboration based on Eurostat 2019). 
Based on data reported by the member states, the EU climate action and the European Green Deal set a plan to cut emissions by 2030 by at least $55 \%$. The ultimate goal is for Europe to become by 2050 the world's first climate-neutral continent. The initiatives and the measures put in place can have an impact if the GHG emissions are cut as the package of measures states and also by investing in research and innovation. In addition, if we compare the EU with other countries/continents, we can say that in 2020 the US withdrawal from the Paris Agreement and the projections were different from the EU. At the same time, China has adopted renewable energy much faster, thus leading to a decrease in GHG emissions [42].

GHG emissions from all operators covered by the European Union Emissions Trading Scheme (ETS) declined by $13.3 \%$ in 2020 compared to 2019. Additionally, in the energy sector the emissions decreased by $14.9 \%$ due to reduced electricity consumption along with using renewable energy that replaced the energy produced using coal. The industrial emissions also decreased by $7 \%$. Considering the fact that in 2020 the COVID-19 pandemic started, the European Commission is not sure whether the emissions decrease can be attributed just to the regulation's efficiency.

Using the data available on Eurostat and applying Excel forecast tools, Figures 2 and 3 were created.

There is a significant decrease in GHG emissions by 2050, as can be seen in Figure 2. If the current plan for the European Union is implemented, then the emissions will decrease by $35 \%$ in 2030 and by $61 \%$ in 2050 compared to 2000 . Additionally, if the analysis is done by taking into consideration 1990, the base year for many researchers, we could see a decrease of $60.25 \%$ by 2050 , so just a $0.75 \%$ difference between the years 1990 and 2000 . A great difference can be seen in Luxembourg, with less than 37\% GHG emissions in 2030 and $76 \%$ in 2050 compared to 2000.

As can be seen from Figure 3, the countries that will change the most are Spain and Portugal from dark blue (values that are very high), and the country that actually will not move forward if the legislation, regulations, and implementation of GHG emissions reduction strategies do not change is Turkey [43]. We chose to add Turkey due to the fact that it demonstrates one of the worst scenarios, where regulations and the implementation of GHG reduction are not properly addressed.

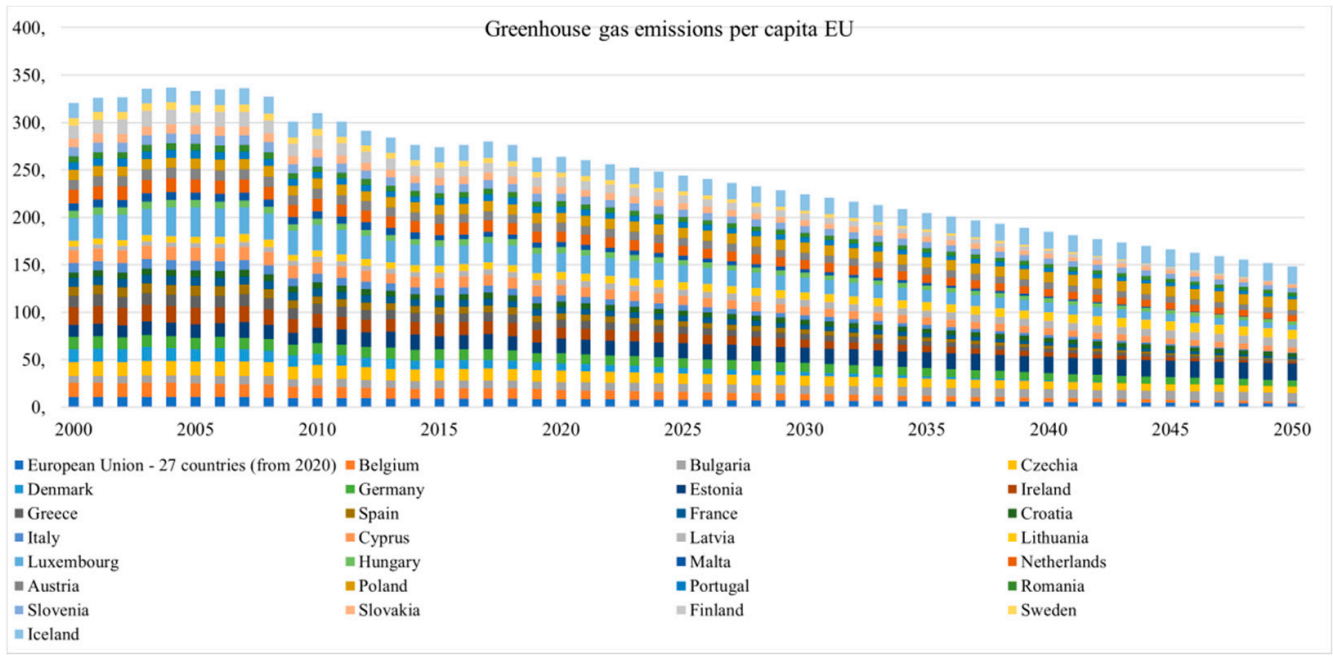

Figure 2. GHG emissions forecast for 2050 per capita (source: own elaboration based on Eurostat 2019). 
Greenhouse gas emissions EU year 2000

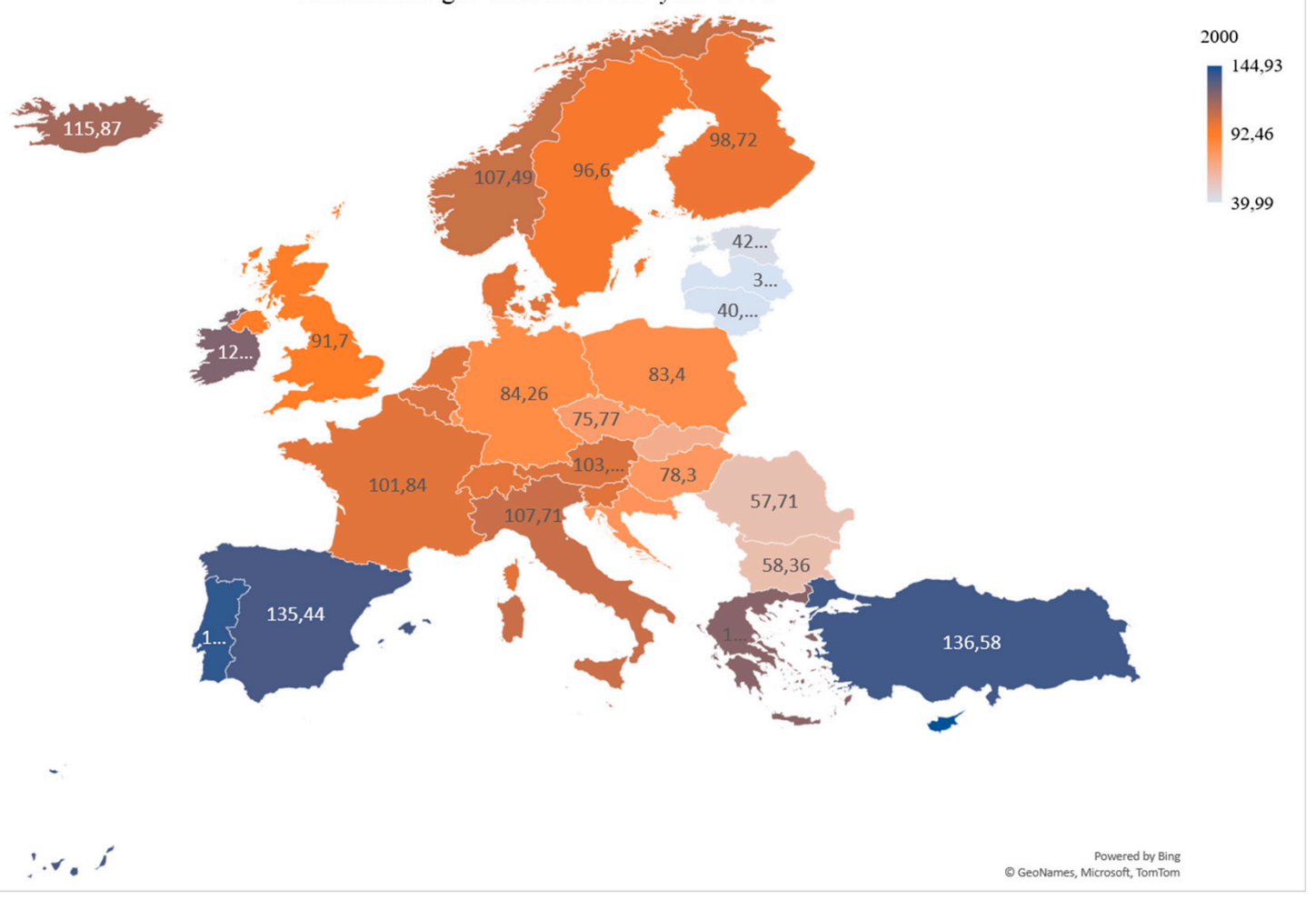

(a)

Greenhouse gas emissions EU year 2018

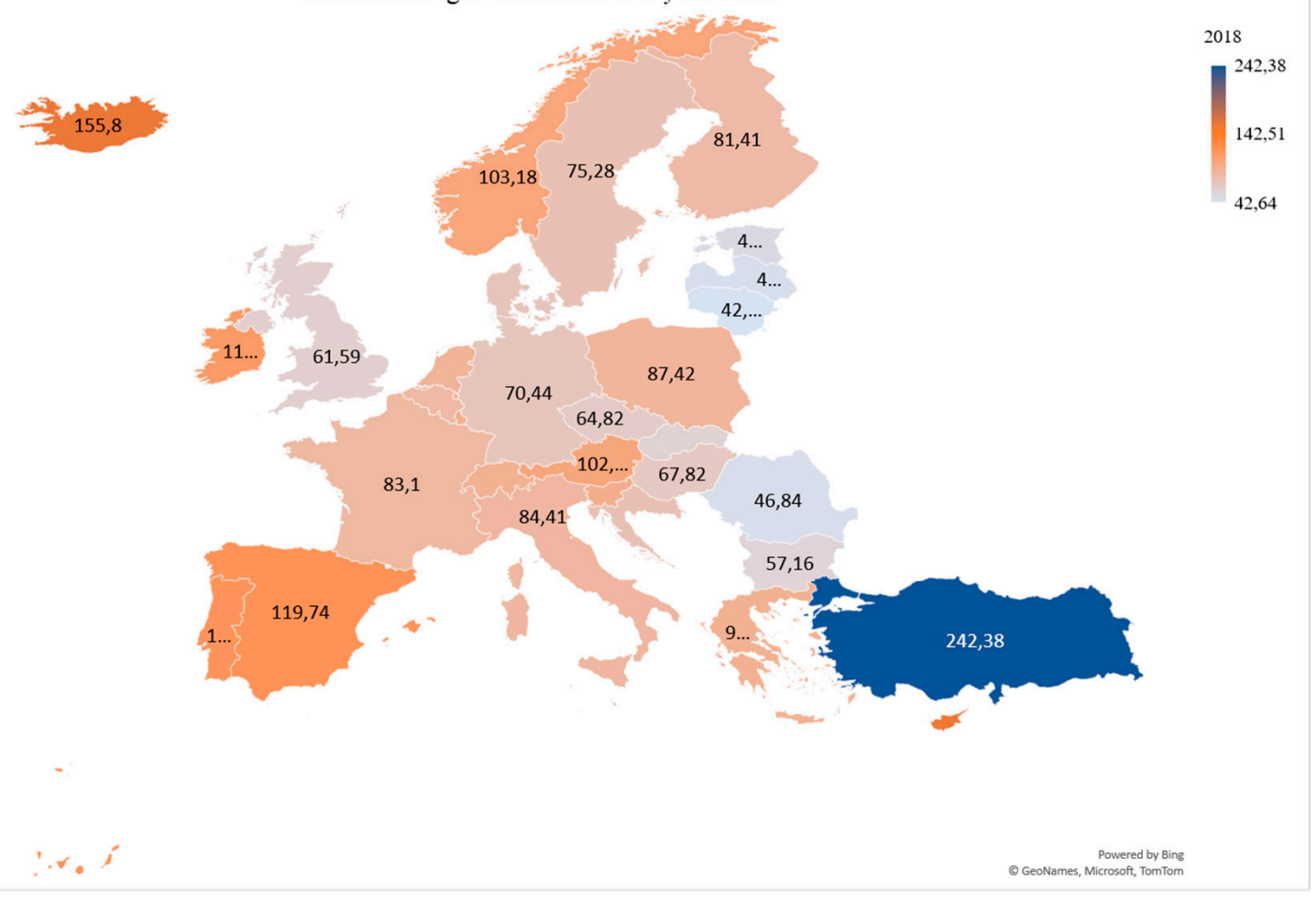

(b)

Figure 3. Cont. 


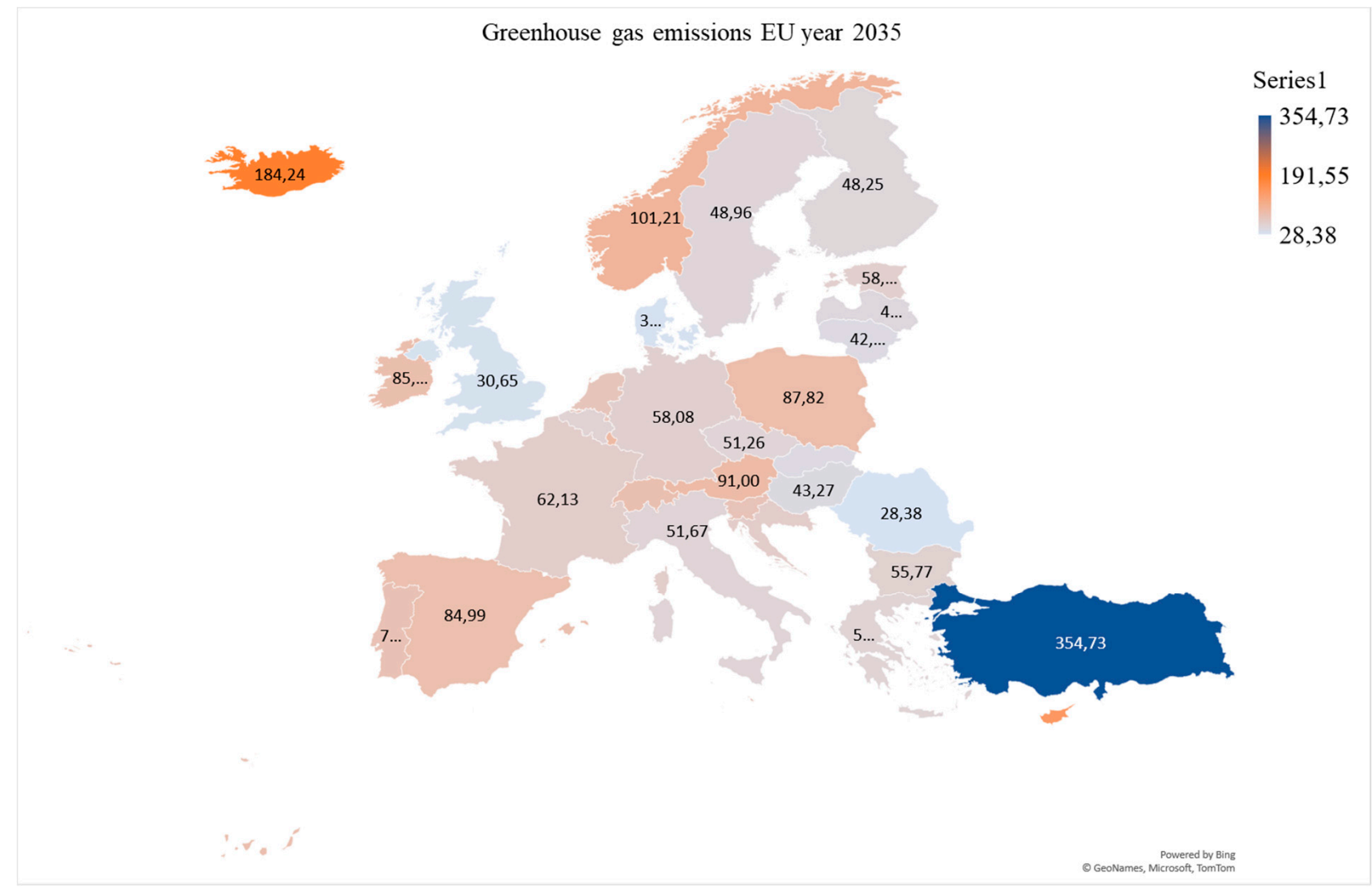

(c)

Greenhouse gas emissions EU year 2050

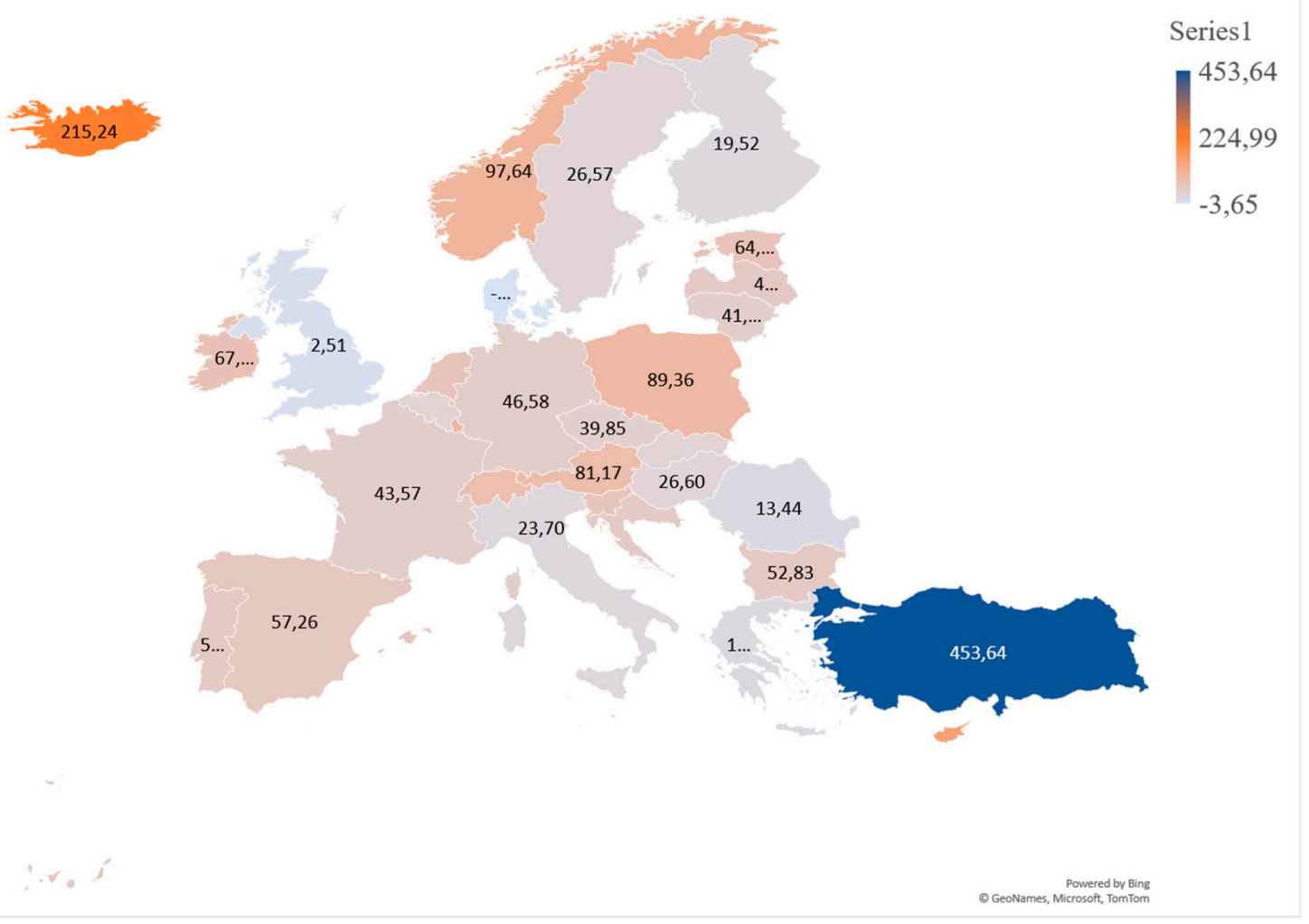

(d)

Figure 3. Map of European GHG emissions per capita (source: own elaboration based on Eurostat 2019 and applying forecasting tools): (a) year 2000, (b) year 2018, (c) year 2035, (d) year 2050. 
It is necessary to keep in mind that we are now in the fourth phase of EU ETS, which applies to 2021-2030 period, in correlation with the Commission Implementing Regulation (EU) 2018/2066 of 19 December 2018, aimed at monitoring and reporting GHG emissions. In addition, during the fourth phase the principles of Stage 3 of the EU ETS remain the same. The main potential value of the EU ETS is to make the price of GHG emissions visible throughout the production and consumption chain, thus paving the way for an efficient low-carbon economy. Only full bidding for emissions can determine their real price, as it is the necessary economic incentive to contribute to this transition. Since 2013, companies must bid in order to obtain an emissions share, shares that are fewer each year than the previous year. For example, in 2020 there were 70.9 million certified emissions reductions (carbon credits) for developing countries and those that are conducting clean development mechanism activities. There was a high number of requests for these credits.

In the same context, Dritsaki and Dritsaki [44] investigated the optimum model to forecast $\mathrm{CO}_{2}$ emissions in the EU-28 based on annual data (from 1960 until 2014). The authors forecasted $\mathrm{CO}_{2}$ emissions for six years (2015-2020) and used an autoregressive integrated moving average (ARIMA) (1,1,1)-autoregressive conditional heteroscedasticity (ARCH) (1) model combined with the linear ARIMA model and the conditional variance of the ARCH model. Their findings support the fact that the year 2020 presented a considerable decrease in $\mathrm{CO}_{2}$ emissions, reaching 33.8\% less than in the year 1990 (Kyoto Protocol) [44].

\subsection{GHG Emissions Analysis and Forecasting in Romania}

A total of 28 states submitted to the EU in 2020 their strategies for lowering GHG emissions in the long term. The ambitious goals for climate change were set while working with a global coalition of countries and international institutions. Despite all this, it seems that the EU needs better knowledge of the GHG emissions reduction plan and regulations.

Romania carries out an annual inventory of GHGs in order to comply with its European obligations and international regulations. Both the annual reporting obligations to the UNFCCC and the EU annual reporting requirements applied to all member states must be met. Specialized GHG services are being developed in Romania as a result for adoption of the Kyoto Protocol [45]. The aspects that are most often considered and can be used by industries of all size operations are:

- Conformity verification, which is done under the international standard ISO 14065. This gives credit for a series of local, regional, and global emissions schemes. The companies that are developing in order to provide this kind of service usually have experience in EU ETS.

- $\quad$ GHG emissions inventory and product verification against internationally accepted standards.

- Carbon footprint - the first step for any business, which means making a verifiable carbon footprint for the organization or product and identifying opportunities to reduce costs by developing low-carbon business strategies and a roadmap for reducing GHG emissions.

Considering the data available on Eurostat, in Figure 4 we have the Romanian GHG emissions that present a descending slope from the first available data in 2000. It can be seen that since 2007, when the emissions had a value of 131,532.46 metric tons, the highest value reported by Romania, the GHG emissions decreased to $91,656.49$ metric tons in 2008, which represents an improvement of $30 \%$. 


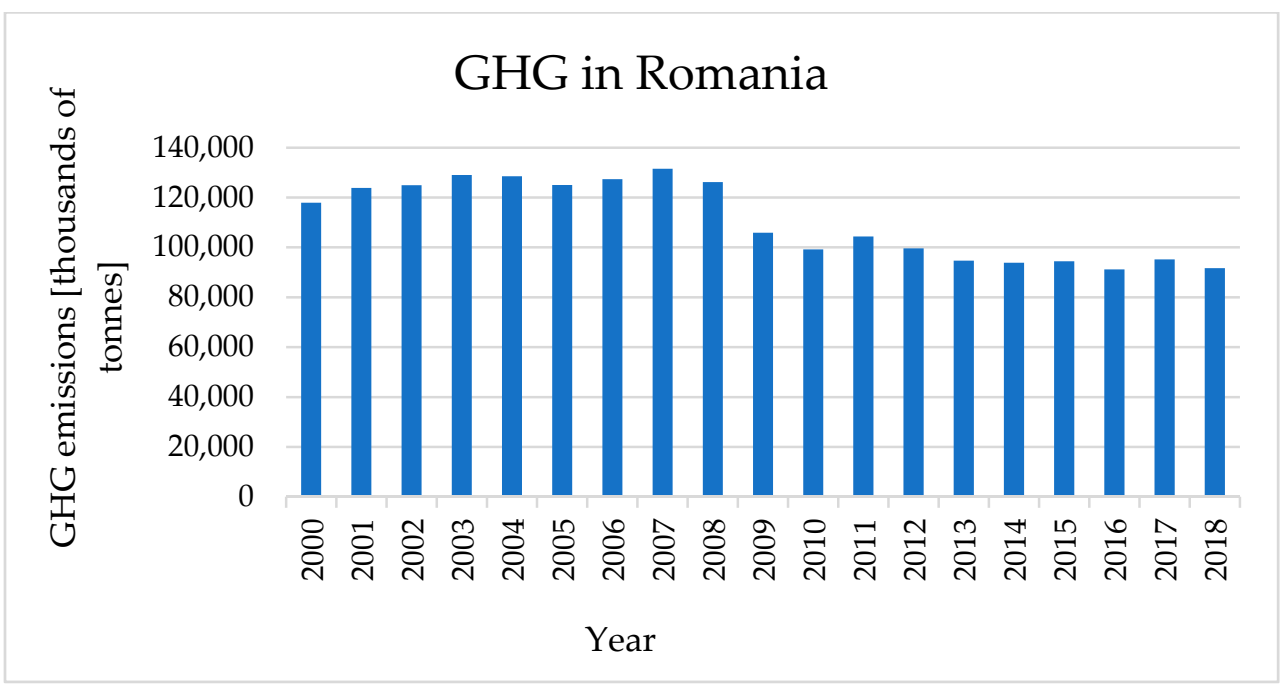

Figure 4. GHG emissions in Romania.

Using the data available on Eurostat and applying Excel forecast tools, Figures 5 and 6 were developed. Since forecast accuracy is a key indicator, it is necessary to mention that at the end of the analysis scientists usually use relative approximation error, root mean squared error, mean absolute percentage error, or mean absolute deviation.

Total Greenhouse Gases emissions in Romania - forecast

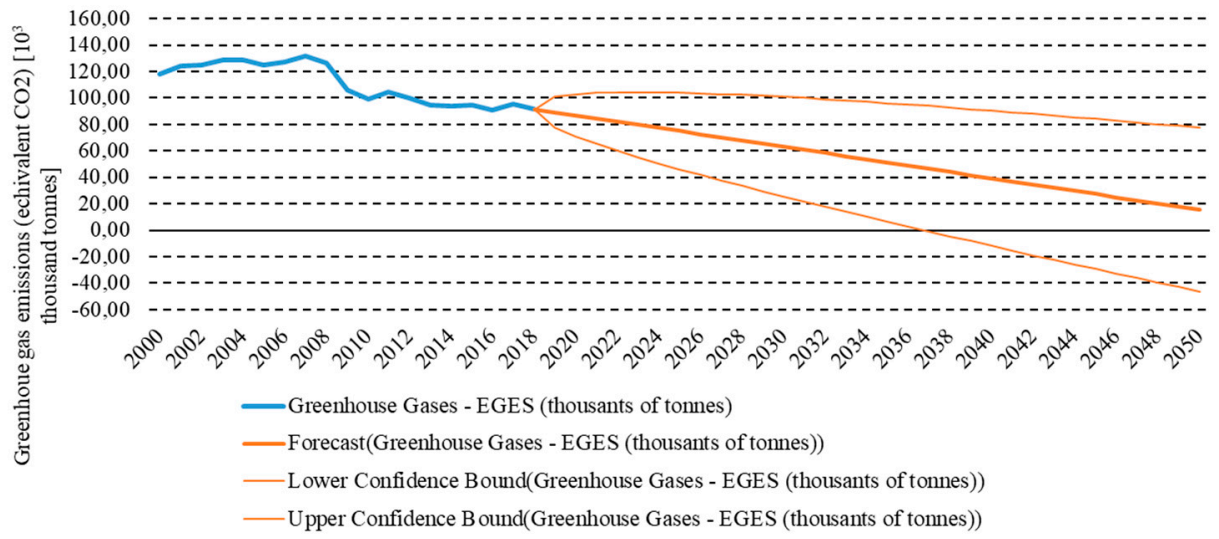

Figure 5. Total GHG emissions in Romania (source: own creation based on Eurostat).

Figure 5 shows the forecast and the boundary values for the confidence interval. To apply this method, a 95\% confidence interval was selected in order to see the future values within this range (calculated as a normal distribution). The smoothing factor $\alpha$ in our forecast was 0.9 , which indicates that the amount of smoothing was reduced, thus more weight could be placed on the more recent observations.

The same forecast tool was also used for the analysis of the emissions intensity of the energy consumption, as shown in Figure 6. The symbol used was $\mathrm{I}_{\mathrm{GES}}$ and the data were measured in a thousand-metric-tons $\mathrm{CO}_{2}$ equivalent. As can be seen, the highest value recorded happened in 2007, with a 90,370.00 metric ton $\mathrm{CO}_{2}$ equivalent, whereas the lowest value of $66,259.00$ metric ton $\mathrm{CO}_{2}$ equivalent was registered in 2016. A 36\% improvement can be seen in 2018 compared to 2007, but a 1\% decrease compared to 2016. Although from 2000 to 2018 the values slightly decreased, the improvement in GHG emissions registered was 18\%. From 2000 to 2007, when the European Commission issued the 2007/589/EC: C Commission Decision of 18 July 2007 establishing guidelines for the monitoring and reporting of GHG emissions, the emissions were increasing year by year, but this regulation 
and others that were issued since then contributed to decreasing GHG emissions due to their implementation among member states.

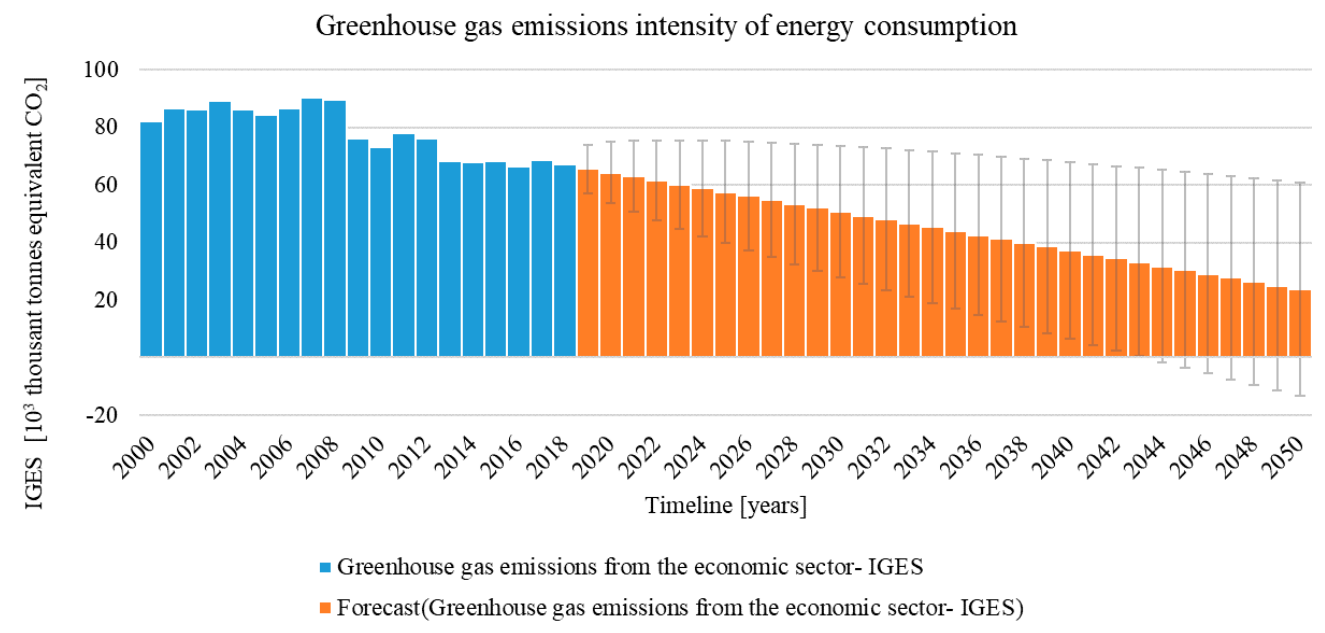

Figure 6. GHG emissions intensity of energy consumption (source: own creation based on Eurostat).

Figure 7 presents just four sectors because these are the largest source sectors of emissions.

The data reported to Eurostat from 2000 to 2018 present that the energy sector was the highest pollutant of GHGs. Their reported value never decreased under a 76,404 thousand metric ton $\mathrm{CO}_{2}$ equivalent, the highest value being recorded in 2003. The emissions quantity decreases were visible mainly between 2007 and 2018, an improvement of 26\%. The difference between the sectors is significant. The next sectors that were close in the reporting numbers (the $\mathrm{CO}_{2}$ equivalent) were industrial processes and product usage and agriculture.

As can be seen in Figure 7, their reported values were in the range of an approximately 19,000 metric ton $\mathrm{CO}_{2}$ equivalent. The highest value recorded in industrial processes and product usage was 22,457.98 in the year 2004, whereas the lowest value was 11,769 in the year 2013. Unfortunately, the decreasing trend was not consistently linear, with the correlation coefficient in this case being $\mathrm{R}^{2}=0.64$. In 2018 , the values reported were $14 \%$ higher than in 2013 and 30\% lower than in 2000. In agriculture, 2018 recorded higher emissions than 2010, when the lowest emissions were recorded. The increase was by $13 \%$ compared to 2010, still 7\% higher than 2000 but a 4\% decrease when compared to 2007. Since 2010, the values of GHG emissions continuously increased year by year and if we do not change the regulations in this sector the emissions registered now will not be much different in 2035 or 2050.

If we analyze the last sector in Figure 7, the waste sector, we can see that although the values reported were lower than in previous sector, the trend was actually increasing. The values registered in 2018 were 5809 metric tons of $\mathrm{CO}_{2}$ equivalent and in 2000, 5303 metric tons of $\mathrm{CO}_{2}$ equivalent. As can be seen, a 9.5\% increase in GHG emissions was recorded. The highest value reported during this time was in 2017, whereas the lowest was in 2011. The GHG emissions from waste in the EU fell by $42 \%$ since 1995, but as can be seen from Romania's data, it is necessary to apply better waste management and regulations. By focusing on recycling and reducing disposal of waste as landfill, many EU member states were able to register lower values for emissions from waste. If Romania changes its waste treatment policies or applies the European regulations as it should, thus creating a more circular economy, then emissions will be reduced and climate change will present a lower impact. The waste sector accounts for about 3\% of total GHG emissions [46]. 
Greenhouse gases emissions by sector

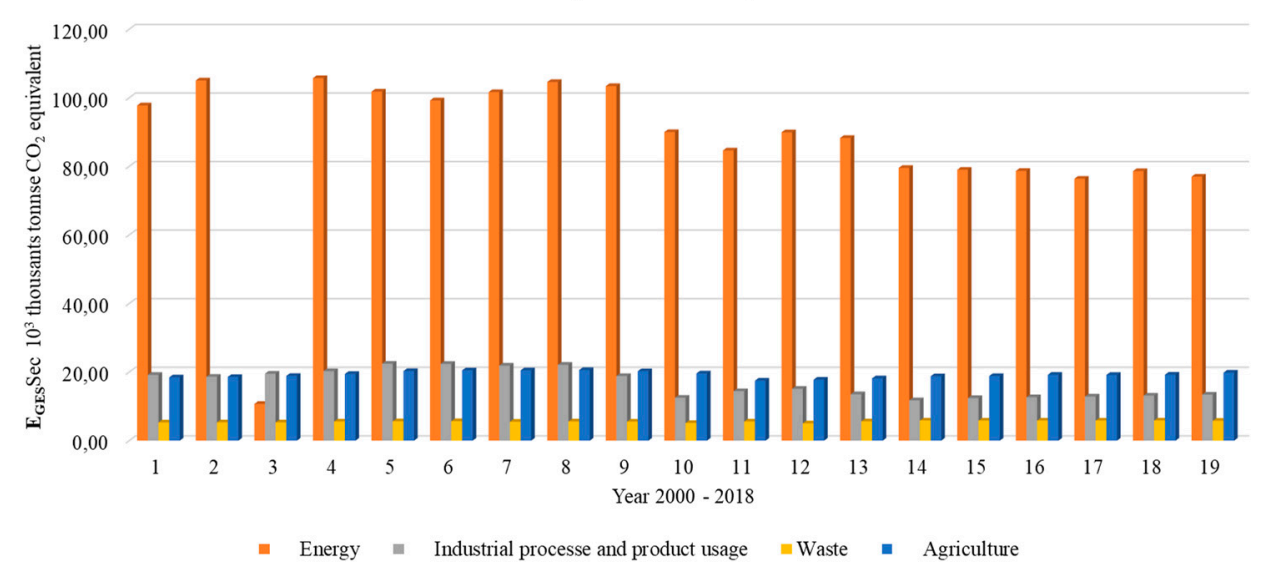

Figure 7. GHG emissions by sector (source: own creation based on Eurostat).

\subsection{GHG Emissions Statistical Analysis in Romania}

\subsubsection{Chronological Series Analysis}

As previously mentioned, the first analysis that was conducted was done by using time series techniques, specifically chronological series ( $\mathrm{SCr}$ ) analysis. The time series techniques were used to look back on patterns of the history of GHG emissions reporting; thus, if we can identify and project the pattern then we have our forecast. Chronological series component analysis can explain the past and present evolution of processes and phenomena but also offers the possibility to predict their behavior in the near or distant future through future projection of evolution models and past behavior. This implies a fundamental supposition that past models and trends that happened in the past will also be valid in the future. This assumption is closer to the truth for the immediate period, whereas for a longer period of time some factors might intervene that can modify the preestablished behavior. Despite the apparently random nature of variable manifestation within a timeframe, usually there is a basic pattern, either theoretical or fundamental, that can be identified, and that contains different elements and reflects the influence of some factors in such a manner that the original series can be reproduced as accurately as possible.

As said, the timeframes are successive and have the same length, so we used SCr of moments with equal timeframes between moments. Knowing this, the median indicators of the chronological time series were calculated.

Medium level for SCr intervals:

$$
\bar{y}=\frac{\sum_{t=1}^{n} y_{t}}{n}=110,746.87 \text { thousand tonnes } \mathrm{CO}_{2} \text { equivalent }
$$

Then the equation for SCr moments with equal intervals between moments is:

$$
\overline{y_{c r}}=\frac{\sum_{i=1}^{n-1} A_{i}}{\sum_{i=1}^{n-1} h}=\frac{\frac{y_{1}}{2}+y_{2}+\cdots+y_{n-1}+\frac{y_{n}}{2}}{n-1}=111,079.16 \text { thousand tonnes } C_{2} \text { equivalent }
$$

The interval length is 1 year.

The absolute average change (absolute average gain) result was:

$$
\bar{\Delta}=\frac{\Delta_{n / 1}}{n-1}=\frac{y_{n}-y_{1}}{n-1}=-1456.18 \text { thousand tonnes } \mathrm{CO}_{2} \text { equivalent. }
$$

Regarding the dynamic average parameter (increase or decrease), the result was:

$$
\bar{I}=\sqrt[n-1]{\frac{y_{n}}{y_{1}}}=0.986
$$


The last indicator of the chronologic series was the dynamic rhythm (relative average change or relative median gain or median increase/decrease ratio):

$$
\bar{R}=(0.986-1) \times 100=-1.4[\%]
$$

Thus, based on the data used we can say that the average GHG emissions is the equivalent of $111,079.16$ metric tons of $\mathrm{CO}_{2}$. The emissions decreased in the analyzed period by an equivalent of 1456.18 metric tons $\mathrm{CO}_{2}$ on average in a year, which means 0.986 times. The dynamic rhythm result shows us that the GHG emissions only decreased by $1.4 \%$. It is necessary to further analyze this dynamic rhythm in a few more years to see whether things have started to change for the better, by not just $1.4 \%$ but, if possible, by a higher percentage.

\subsubsection{GHG Emissions Analytical Method Analysis}

Analytical methods offer a more exact adjustment of the chronological series because they consider all the chronological series terms. These methods assume using the appropriate mathematical/analytical functions to determine the trend values. The fundamental problem is choosing the right type of function, also called the trend adjustment function. Most used functions are linear, polynomial, hyperbolic, exponential, logistics, and parabolic. Choosing one function can be done by graphic representation. The data gathered from Eurostat is a chronological series formed from an odd number of terms, so in this case the central point of the series was $t=0$ and the rest of the terms were symmetrical to that one.

Using graphical representation, in Figures 8 and 9 we can see the GHG emissions trend in Romania both for linear and exponential analysis. As can be observed from the correlation coefficient, the linear trend analysis was a better fit because $R^{2}=0.7557$, unlike $\mathrm{R}^{2}=0.7376$ for the exponential trendline analysis. The difference between the correlation coefficients was not significant, which is why this both methods are acceptable but still will need further analysis in the future.

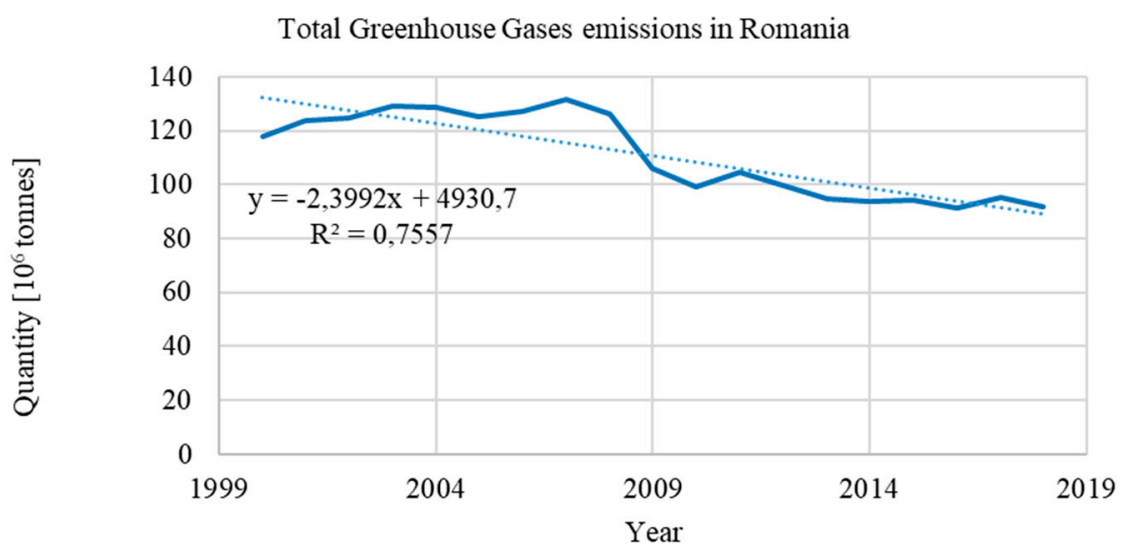

Figure 8. Total greenhouse emissions in Romania-linear trend analysis.

For the linear analysis the parameters $a$ and $b$ are:

$$
\begin{aligned}
& a=\frac{\sum \mathrm{y}_{\mathrm{t}}}{\mathrm{n}}=\overline{\mathrm{y}}=\frac{2,104,190.6}{19}=110,746.87 \\
& b=\frac{\sum t \times y_{t}}{\sum t^{2}}=\frac{-1,367,537.61}{570}=-2399.19
\end{aligned}
$$

Thus, the equation that describes the linear trend analysis is:

$$
\hat{y}_{t}=a+b t=110,746.87-2399.19 t
$$

The values were calculated and are presented in Table 2 . 


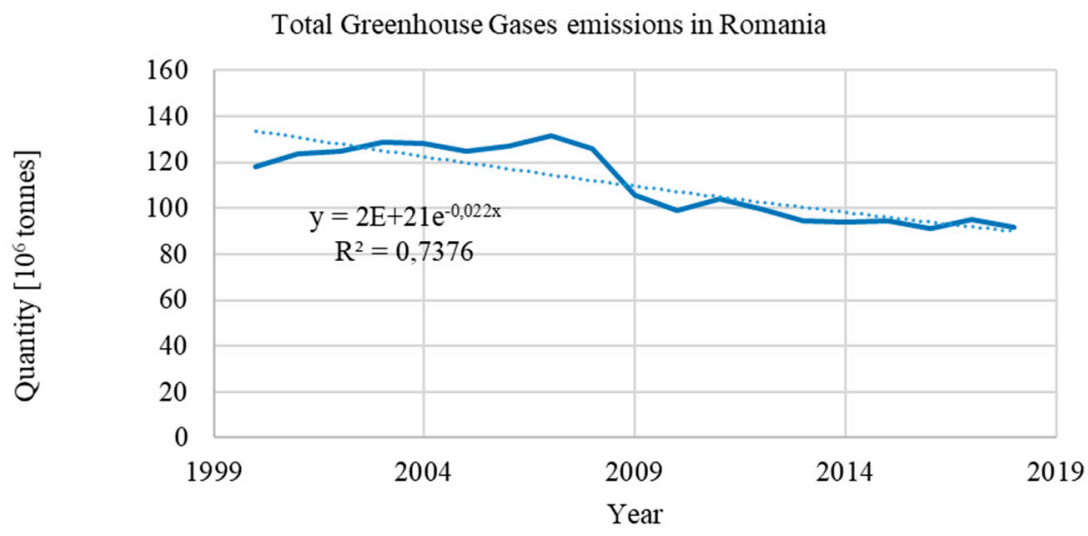

Figure 9. Total greenhouse emissions in Romania-exponential trend analysis.

Table 2. Linear trend analysis of total GHG emissions in Romania.

\begin{tabular}{cccccccc}
\hline Years & $y_{t}$ & $t$ & $t^{\mathbf{2}}$ & $T^{*} y_{t}$ & $\hat{y}_{t}$ & $y_{t}-\hat{y}_{t}$ & $\left(y_{t}-\hat{y}_{t}\right)^{2}$ \\
\hline 2000 & $117,874.98$ & -9 & 81 & $-1,060,874.81$ & $132,339.57$ & $-14,464.59$ & $209,224,480.20$ \\
2001 & $123,818.21$ & -8 & 64 & $-990,545.67$ & $129,940.38$ & -6122.18 & $37,481,036.11$ \\
2002 & $124,891.01$ & -7 & 49 & $-874,237.07$ & $127,541.20$ & -2650.19 & $7,023,481.72$ \\
2003 & $129,051.47$ & -6 & 36 & $-774,308.82$ & $125,142.01$ & 3909.46 & $15,283,899.33$ \\
2004 & $128,491.31$ & -5 & 25 & $-642,456.55$ & $122,742.82$ & 5748.49 & $33,045,155.10$ \\
2005 & $125,006.10$ & -4 & 16 & $-500,024.41$ & $120,343.63$ & 4662.47 & $21,738,667.06$ \\
2006 & $127,334.60$ & -3 & 9 & $-382,003.79$ & $117,944.44$ & 9390.16 & $88,175,056.12$ \\
2007 & $131,532.46$ & -2 & 4 & $-263,064.92$ & $115,545.25$ & $15,987.21$ & $255,590,918.54$ \\
2008 & $126,179.68$ & -1 & 1 & $-126,179.68$ & $113,146.06$ & $13,033.62$ & $169,875,172.92$ \\
2009 & $105,847.91$ & 0 & 0 & 0.00 & $110,746.87$ & -4898.96 & $23,999,799.10$ \\
2010 & $99,170.01$ & 1 & 1 & $99,170.01$ & $108,347.68$ & -9177.67 & $84,229,655.73$ \\
2011 & $104,377.84$ & 2 & 4 & $208,755.68$ & $105,948.50$ & -1570.66 & $2,466,960.03$ \\
2012 & $99,615.38$ & 3 & 9 & $298,846.15$ & $103,549.31$ & -3933.92 & $15,475,752.92$ \\
2013 & $94,638.20$ & 4 & 16 & $378,552.80$ & $101,150.12$ & -6511.92 & $42,405,083.14$ \\
2014 & $93,878.21$ & 5 & 25 & $469,391.05$ & $98,750.93$ & -4872.72 & $23,743,397.79$ \\
2015 & $94,448.55$ & 6 & 36 & $566,691.30$ & $96,351.74$ & -1903.19 & $3,622,135.83$ \\
2016 & $91,182.74$ & 7 & 49 & $638,279.18$ & $93,952.55$ & -2769.81 & $7,671,859.43$ \\
2017 & $95,195.44$ & 8 & 64 & $761,563.52$ & $91,553.36$ & 3642.08 & $13,264,722.16$ \\
2018 & $91,656.49$ & 9 & 81 & $824,908.41$ & $89,154.17$ & 2502.32 & $6,261,582.46$ \\
TOTAL & $\mathbf{2 , 1 0 4 , 1 9 0 . 6 0}$ & $\mathbf{0 . 0 0}$ & $\mathbf{5 7 0}$ & $\mathbf{- 1 , 3 6 7 , 5 3 7 . 6 1}$ & $\mathbf{2 , 1 0 4 , 1 9 0 . 6 0}$ & $\mathbf{0 . 0 0}$ & $\mathbf{1 , 0 6 0 , 5 7 8 , 8 1 5 . 7 1}$ \\
\hline
\end{tabular}

As can be seen, the resulting equation was the linear trend equation for which the correlation coefficient is equal to 1 . It can be observed that the analysis was correct because the sum of the GHG emissions reported and the sum of the GHG emissions adjusted are equal. After calculating the relative approximation error for the linear trend analysis, we can say that the forecast accuracy is high because it is below $10 \%$.

$$
\varepsilon=5.44 \%
$$

For the exponential method we used the equation above to determine the parameters, so they were:

$$
\begin{gathered}
\log a=\frac{\sum \log y_{t}}{n}=\frac{95.76}{19}=5.04 \\
\log b=\frac{\sum t \times \log y_{t}}{\sum t^{2}}=\frac{-5.46}{570}=-0.00957
\end{gathered}
$$

Thus,

$$
\begin{gathered}
a=109,711.5 \\
b=0.978
\end{gathered}
$$


In this case the exponential equation will be:

$$
\hat{y}_{t}=a \times b^{t}=109,711.5 \times 0.978^{t}
$$

The values were calculated based on Table 3 .

Table 3. Exponential trend analysis of total GHG emissions in Romania.

\begin{tabular}{cccccccc}
\hline Years & $y_{t}$ & $\boldsymbol{t}$ & $\boldsymbol{t}^{\mathbf{2}}$ & $T^{*} \boldsymbol{y}_{t}$ & $\hat{y}_{t}$ & $\boldsymbol{y}_{t}-\hat{y}_{t}$ & $\left(\boldsymbol{y}_{t}-\hat{y}_{t}\right)^{2}$ \\
\hline 2000 & $117,874.98$ & -9 & 81 & $-1,060,874.81$ & $132,339.57$ & $-14,464.59$ & $209,224,480.20$ \\
2001 & $123,818.21$ & -8 & 64 & $-990,545.67$ & $129,940.38$ & -6122.18 & $37,481,036.11$ \\
2002 & $124,891.01$ & -7 & 49 & $-874,237.07$ & $127,541.20$ & -2650.19 & $7,023,481.72$ \\
2003 & $129,051.47$ & -6 & 36 & $-774,308.82$ & $125,142.01$ & 3909.46 & $15,283,899.33$ \\
2004 & $128,491.31$ & -5 & 25 & $-642,456.55$ & $122,742.82$ & 5748.49 & $33,045,155.10$ \\
2005 & $125,006.10$ & -4 & 16 & $-500,024.41$ & $120,343.63$ & 4662.47 & $21,738,667.06$ \\
2006 & $127,334.60$ & -3 & 9 & $-382,003.79$ & $117,944.44$ & 9390.16 & $88,175,056.12$ \\
2007 & $131,532.46$ & -2 & 4 & $-263,064.92$ & $115,545.25$ & $15,987.21$ & $255,590,918.54$ \\
2008 & $126,179.68$ & -1 & 1 & $-126,179.68$ & $113,146.06$ & $13,033.62$ & $169,875,172.92$ \\
2009 & $105,847.91$ & 0 & 0 & 0.00 & $110,746.87$ & -4898.96 & $23,999,799.10$ \\
2010 & $99,170.01$ & 1 & 1 & $99,170.01$ & $108,347.68$ & -9177.67 & $84,229,655.73$ \\
2011 & $104,377.84$ & 2 & 4 & $208,755.68$ & $105,948.50$ & -1570.66 & $2,466,960.03$ \\
2012 & $99,615.38$ & 3 & 9 & $298,846.15$ & $103,549.31$ & -3933.92 & $15,475,752.92$ \\
2013 & $94,638.20$ & 4 & 16 & $378,552.80$ & $101,150.12$ & -6511.92 & $42,405,083.14$ \\
2014 & $93,878.21$ & 5 & 25 & $469,391.05$ & $98,750.93$ & -4872.72 & $23,743,397.79$ \\
2015 & $94,448.55$ & 6 & 36 & $566,691.30$ & $96,351.74$ & -1903.19 & $3,622,135.83$ \\
2016 & $91,182.74$ & 7 & 49 & $638,279.18$ & $93,952.55$ & -2769.81 & $7,671,859.43$ \\
2017 & $95,195.44$ & 8 & 64 & $761,563.52$ & $91,553.36$ & 3642.08 & $13,264,722.16$ \\
2018 & $91,656.49$ & 9 & 81 & $824,908.41$ & $89,154.17$ & 2502.32 & $6,261,582.46$ \\
TOTAL & $\mathbf{2 , 1 0 4 , 1 9 0 . 6 0}$ & $\mathbf{0 . 0 0}$ & $\mathbf{5 7 0}$ & $\mathbf{- 1 , 3 6 7 , 5 3 7 . 6 1}$ & $\mathbf{2 , 1 0 4 , 1 9 0 . 6 0}$ & $\mathbf{0 . 0 0}$ & $\mathbf{1 , 0 6 0 , 5 7 8 , 8 1 5 . 7 1}$ \\
\hline
\end{tabular}

In addition, for the exponential trend analysis the relative approximation error was calculated, but the result was above $10 \%$, which shows that this method is not accurate.

Considering the results, we can make a choice regarding the optimum method using the following criteria:

- We select the graphic representation of the adjusted chronological series that best fits the real values;

- We select the chronological series trend function for which the sum of the adjusted values is closest to the real values;

- We select the adjusted function for which the sum of the squares of the differences between the adjusted and real values is minimum;

- We select the function that has the minimum mean square deviation.

Considering all the criteria between the two analytical methods used for analyzing the total GHG emissions, we can say that the most exact method is the linear trend method.

\begin{tabular}{cc}
\hline The Adjusted Method & $\sum\left(y_{y}-\hat{y}_{t}\right)^{2}$ \\
Linear function method & $1,060,578,815.71$ \\
Exponential function method & $7,231,706,537.04$ \\
\hline
\end{tabular}

The criteria selection is also sustained by the relative approximation error that was calculated.

$$
\begin{gathered}
\varepsilon_{\text {linear }}<\varepsilon_{\text {exponential }} \\
5.44 \%<12.32 \%
\end{gathered}
$$

Although the results were achieved using the basics tools for a statistic analysis, they revealed that if we do not apply the proper method for analysis then we will not be able to predict the emissions as close to what actually happens as we would like. For example, as seen from the relative approximation error, the exponential forecast leads to different 
results. The methods used in the paper were selected to be expressed in a simple way in order to be easily understood by scientists and interested people in the changes in GHG emissions.

\subsection{Study Limitations}

For a great quality analysis it is necessary to mention the limitations.

Although the forecasting method used in the article is conventional and expressed good results, future research should consider combining both conventional and newly developed methods of forecast analysis. The recommendation to combine them comes from the fact that each method has its own advantages and limitations and only together can they present accurate results.

Significant results can be obtained using conventional forecast methods that use statistical modeling/analysis based on mathematical models that provide statistical diagnostic significance tests and using machine learning models that can accelerate data processing, automate forecasts, and increase adaptability to changes.

Due to the fact that the data collected had a clear period of time, the chronological analysis was a good fit, but to sustain the results, more combined methods should be considered because every analysis has its own limitations, including this method.

In this respect, in our future analysis we intend to analyze future data related to GHGs using IT tools, but for the start of our research we limited the analysis to the basics (forecasting tool from Excel).

\section{Conclusions}

Due to technological development in the past 30 years, the environment suffered changes that have had an impact on the environment in the long term, thus affecting the life of future generations. Because people's needs increased in this time, the GHG emissions that resulted from these processes also increased.

Thus, this paper highlights the GHG emissions and the importance of good emissions management. Based on the results of our research, it can be seen that statistics are a tool that can be used in predicting GHG emissions for the conditions that the current factors do not change. The regulations and policies that are adapted year by year influence any analysis. Environmental management and analysis tools are needed and should constitute an important part of the sustainable development plan. Assessing the situation based on known data will help stakeholders make better and more informed decisions.

A better system that can be used for calculating and monitoring GHG emissions is at the moment a requirement not just for Romania but for other countries as well. This conclusion can be drawn from the dynamic rhythm calculated that showed only a $1.4 \%$ improvement in the reduction of GHG emissions.

In addition, from the analytical methods used we can draw the conclusion that emissions are on a descending scale and choosing a proper method is important in analyzing data.

Regarding the results presented in the paper, it must be mentioned that one weakness that the forecast method should have addressed is using more analysis methods. Using more methods could have ensured a larger comparison between the results, thus resulting in a more accurate forecast. At the same time, the use of chronological series and the analytical methods analysis both showed a decrease in GHG emissions.

The forecasting tool from Excel showed that in the time analyzed, some improvements were made, and if we move forward in the future using the current regulations and policies, it is possible to achieve the Green Deal goal. Of course, the stakeholders' attitude towards changing and adapting to the EU directives will highly influence the future outcome.

Although in Europe there are states that are making considerable progress, there are still other countries like Romania that need support to implement the proper tools. Therefore, in order to see improvement in the numbers reported to the EU, in Romania it is necessary to: 
- Ensure transparency in the emissions quantity for each stakeholder, disregarding the sector;

- Include better rights and obligations for stakeholders;

- Provide the tools / means to change the current processes to sustainable, zero emissions ones;

- Offer state grants for companies adapting to green energy and zero emissions;

- Implement proper legislation for selecting, managing, and monitoring waste, using green energy for recycling;

- Maintain a decrease of at least $1.4 \%$ in GHG emissions, as shown in our analysis;

- Maintain a descending trend in the values GHG emissions generated and gathered, which are then reported to the EU;

- Use the proper statistical methods to analyze the trends in GHGs emissions (from our research, linear trend analysis is one option);

- Implement, on a national scale, carbon recovery machines or high-carbon-using trees in every part of the country.

In addition, the improvements mentioned before can be achieved only by conducting future scientific research on GHG emissions. One important indicator that should be analyzed is the carbon footprint, which is easy to understand since there is global interest in it and it is measured in quantitative units, but still, it is necessary to keep in mind that one weakness is the insufficient accuracy of the data. Future research should analyze each industry by itself and its GHG emissions, and from the results develop the proper tools for successful GHG emissions reduction.

Author Contributions: Conceptualization, G.M. and M.N.D.; methodology, G.M. and M.N.D.; validation, G.M. and M.N.D.; formal analysis, G.M. and M.N.D.; investigation, G.M. and M.N.D.; resources, G.M. and M.N.D.; data curation, G.M. and M.N.D.; writing—original draft preparation, G.M. and M.N.D.; writing—review and editing, G.M. and M.N.D.; visualization, G.M. and M.N.D.; supervision, G.M. and M.N.D. All authors have read and agreed to the published version of the manuscript.

Funding: This research received no external funding.

Institutional Review Board Statement: Not applicable.

Informed Consent Statement: Not applicable.

Conflicts of Interest: The authors declare no conflict of interest.

\section{References}

1. Lindsey, R.; Dahlman, L. Climate Change: Global Temperature. 2021. Available online: https:/ /www.climate.gov/news-features / understanding-climate/climate-change-global-temperature (accessed on 14 October 2021).

2. Institute of Atmospheric Physics, Chinese Academy of Sciences. Earth's Climate to Increase by 4 Degrees by 2084 . Available online: https:/ / www.eurekalert.org/news-releases/796802 (accessed on 14 October 2021).

3. Wang, X.; Jiang, D.; Lang, X. Climate change of $4{ }^{\circ} \mathrm{C}$ global warming above pre-industrial levels. Adv. Atmos. Sci. 2018, 35, 757-770. [CrossRef]

4. $\quad$ Betts, R.A.; Collins, M.; Hemming, D.L.; Jones, C.D.; Lowe, J.A.; Sanderson, M. When could global warming reach $4{ }^{\circ} \mathrm{C}$ ? Phil. Trans. R. Soc. A 2011, 369, 67-84. [CrossRef]

5. Liu, P.R.; Raftery, A.E. Country-based rate of emissions reductions should increase by $80 \%$ beyond nationally determined contributions to meet the $2{ }^{\circ} \mathrm{C}$ target. Commun. Earth Environ. 2021, 2, 1-10. [CrossRef] [PubMed]

6. World Meteorological organization. The State of the Global Climate 2020. Available online: https://public.wmo.int/en/ourmandate/climate/wmo-statement-state-of-global-climate\%20 (accessed on 14 October 2021).

7. Sustainable Development Report 2019. Available online: https://sdgindex.org/reports/sustainable-development-report-2019/ (accessed on 21 August 2021).

8. European Commission. Conference on the Future of Europe. Available online: https://ec.europa.eu/info/index_en (accessed on 21 August 2021).

9. European Commission. European Green Deal: Comission Proposes Transformation of EU Economy and Society to Meet Climate Ambitions. Available online: https:/ / ec.europa.eu/commission/presscorner/detail/en/ip_21_3541 (accessed on 14 October 2021). 
10. Rongyun, T.; Jiafu, M.; Mingzhou, J.; Anping, C.; Yan, Y.; Xiaoying, S.; Yulong, Z.; Forrest, M.H.; Min, X.; Yaoping, W. Interannual variability and climatic sensitivity of global wildfire activity. Adv. Clim. Chang. Res. 2021, 12, 686-695. [CrossRef]

11. King, W.; Bhattacharya, A.; Bolch, T. The presence and influence of glacier surging around the Geladandong ice caps, North East Tibetan Plateau. Adv. Clim. Chang. Res. 2021, 12, 299-312. [CrossRef]

12. Fu, Y.H.; Gao, X.J.; Zhu, Y.M.; Guo, D. Climate change projection over the Tibetan Plateau based on a set of RCM simulations. Adv. Clim. Chang. Res. 2021, 12, 313-321. [CrossRef]

13. Mulomba Mukadi, P.; González-García, C. Time Series Analysis of Climatic Variables in Peninsular Spain. Trends and Forecasting Models for Data between 20th and 21st Centuries. Climate 2021, 9, 119. [CrossRef]

14. Seater, J.J. World temperature-trend uncertainties and their implications for economic policy. J. Bus. Econ. Stat. 1993, 11, 265-277.

15. Harvey, D.I.; Mills, T.C. Modelling global temperature trends using cointegration and smooth transition. Stat. Model. 2001, 1, 143-159. [CrossRef]

16. Mudelsee, M. Trend analysis of climate time series: A review of methods. Earth Sci. Rev. 2019, 190, 310-322. [CrossRef]

17. Boscolo-Galazzo, F.; Crichton, K.A.; Ridgwell, A.; Mawbey, E.M.; Wade, B.S.; Pearson, P.N. Temperature controls carbon cycling and biological evolution in the ocean twilight zone. Science 2021, 371, 1148. [CrossRef] [PubMed]

18. Crowther, T.W.; van den Hoogen, J.; Wan, J.; Mayes, M.A.; Keiser, A.D.; Mo, L.; Averill, C.; Maynard, D.S. The global soil community and its influence on biogeochemistry. Science 2019, 365, eaav0550. [CrossRef]

19. Wang, S.; Maltrud, M.; Elliott, S.; Cameron-Smith, P.; Jonko, A. Influence of dimethyl sulfide on the carbon cycle and biological production. Biogeochemistry 2018, 138, 49-68. [CrossRef]

20. Climate Change Indicators and Impacts Worsened 2020. Available online: https://public.wmo.int/en/media/press-release/ climate-change-indicators-and-impacts-worsened-2020 (accessed on 16 August 2021).

21. Arora, N.K.; Fatima, T.; Mishra, I.; Verma, M.; Mishra, J.; Mishra, V. Environmental sustainability: Challenges and viable solutions Environ. Sustain. 2018, 1, 309-340. [CrossRef]

22. Hongguang, L.; Weidong, L.; Xiaomei, F.; Zhipeng, T. Global research trends related to $\mathrm{CO}_{2}$ emissions and their enlightenment to China. Chin. J. Popul. Resour. Environ. 2012, 10, 3-12. [CrossRef]

23. Majumder, S.C.; Islam, K.; Hossain, M.M. State of research on carbon sequestration in Bangladesh: A comprehensive review. Geol. Ecol. Landsc. 2019, 3, 29-36. [CrossRef]

24. Mohammed, S.; Mousavi, M.; Alsafadi, K.; Bramdeo, K. Tracking GHG Emission from Agricultural and Energy Sectors in the EU from 1990 to 2016. Abstract Book of the 18th Alps-Adria Scientific Workshop. 2019; pp. 114-115. Available online: https: / / www.researchgate.net/publication/332387952_Tracking_GHG_emission_from_agricultural_and_energy_sectors_ in_the_EU_from_1990_to_2016 (accessed on 17 August 2021).

25. EUR-Lex. Kyoto Protocol on Climate Change. Available online: https://eur-lex.europa.eu/summary/EN/legissum:128060 (accessed on 17 August 2021).

26. Aprill, M.; O'Neil, J.K. Greenhouse Gases and Sustainable Development. In Encyclopedia of Sustainability in Higher Education; Leal Filho, W., Ed.; Springer: Cham, Switzerland, 2019. [CrossRef]

27. Global Greenhouse Gas Emissions Data, United States Environmental Protection Agency. Available online: https://www.epa. gov / ghgemissions/global-greenhouse-gas-emissions-data (accessed on 21 August 2021).

28. Alhindawi, R.; Abu Nahleh, Y.; Kumar, A.; Shiwakoti, N. Projection of greenhouse gas emissions for the road transport sector based on Multivariate Regression and the double exponential smoothing model. Sustainability 2020, 12, 9152. [CrossRef]

29. Andrejiova, M.; Grincova, A.; Marasova, D. Study of the percentage of greenhouse gas emissions from aviation in the EU-27 countries by applying Multiple-Criteria Statistical Methods. Int. J. Environ. Res. Public Health 2020, 17, 3759. [CrossRef]

30. Saleh, C.; Dzakiyullah, N.R.; Nugroho, J.B. Carbon dioxide emission prediction using support vector machine. IOP Conf. Ser. Mater. Sci. Eng. 2016, 114, 012148. [CrossRef]

31. Li, M.; Wang, W.; De, G.; Ji, X.; Tan, Z. Forecasting Carbon Emissions Related to Energy Consumption in Beijing-Tianjin-Hebei Region Based on Grey Prediction Theory and Extreme Learning Machine Optimized by Support Vector Machine Algorithm. Energies 2018, 11, 2475. [CrossRef]

32. Zhou, J.G.; Zhang, X.G. Projections about Chinese $\mathrm{CO}_{2}$ emissions based on rough sets and gray support vector machine. Chin. Environ. Sci. 2013, 33, 2157-2163.

33. Sun, W.; Jin, H.; Wang, X. Predicting and Analyzing $\mathrm{CO}_{2}$ Emissions Based on an Improved Least Squares Support Vector Machine. Pol. J. Environ. Stud. 2019, 28, 4391-4401. [CrossRef]

34. Lee, K.M.; Lee, M.H.; Lee, S.L.; Joo, Y.L. Uncertainty Analysis of Greenhouse Gas (GHG) Emissions Simulated by the Parametric Monte Carlo Simulation and Nonparametric Bootstrap Method. Energies 2020, 13, 4965. [CrossRef]

35. Akyol, M.; Uçar, E. Carbon footprint forecasting using time series data mining methods: The case of Turkey. Environ. Sci. Pollut. Res. 2021, 28, 38552-38562. [CrossRef]

36. Kijewska, A.; Bluszcz, A. Analysis of greenhouse gas emissions in the European Union member states with the use of an agglomeration algorithm. J. Sustain. Min. 2016, 15, 133-142. [CrossRef]

37. Ding, Y.J.; Wu, P.C.; Lian, Y.H. Time Series Analysis for the Dynamic Relationship between an Enterprise's Business Growth and Carbon Emission in Taiwan. Sustainability 2020, 12, 5560. [CrossRef]

38. Tubiello, F.N.; Biancalani, R.; Salvatore, M.; Rossi, S.; Conchedda, G. A worldwide assessment of greenhouse gas emissions from drained organic soils. Sustainability 2016, 8, 371. [CrossRef] 
39. Zafeiriou, E.; Mallidis, I.; Galanopoulos, K.; Arabatzis, G. Greenhouse gas emissions and economic performance in EU Agriculture: An Empirical Study in a Non-Linear Framework. Sustainability 2018, 10, 3837. [CrossRef]

40. Liu, X.; Zhang, S.; Bae, J. The impact of renewable energy and agriculture on carbon dioxide emissions: Investigating the environmental Kuznets curve in four selected ASEAN countries. J. Clean. Prod. 2017, 164, 1239-1247. [CrossRef]

41. Romania's Fourth Biennial Report under the UNFCCC, 2020, Ministry of Environment, Waters and Forests. Available online: https:/ / unfccc.int/sites/default/files/resource/BR4_Romania.pdf (accessed on 26 August 2021).

42. Zimmer, M.; Dang, A.; Holzhausen, A.; Patel, D.U.S. Europe or China: Who Is the Global Climate's Superhero? 2020; pp. 1-20. Available online: https://www.eulerhermes.com/content/dam/onemarketing/ehndbx/eulerhermes_com/en_gl/erd/ publications/pdf/2020_10_21_ClimatePolicy.pdf (accessed on 26 August 2021).

43. Turkish Greenhouse Gas Inventory 1990-2019. National Inventory Report for submission under the United Nations Framework Convention on Climate Change. Turkish Statistical Institute. 2021. Available online: https://unfccc.int/documents/271544 (accessed on 14 October 2021).

44. Dritsaki, M.; Dritsaki, C. Forecasting European Union $\mathrm{CO}_{2}$ Emissions Using Autoregressive Integrated Moving Averageautoregressive Conditional Heteroscedasticity Models. Int. J. Energy Econ. Policy 2020, 10, 411-423. [CrossRef]

45. Greenhouse Gas Emissions Solutions. Available online: https://www.sgsgroup.ro/ro-ro/environment-health-and-safety/ compliance-and-auditing/greenhouse-gas-emissions-solutions (accessed on 21 August 2021).

46. Greenhouse Gas Emissions from Waste. Available online: https://ec.europa.eu/eurostat/web/products-eurostat-news/-/DDN20200123-1 (accessed on 26 August 2021). 